\title{
Perencanaan Model Bisnis pada UMKM dalam Mengembangkan Oleh-oleh Khas Bekasi
}

\author{
Jati Paras Ayu \\ Institut Komunikasi dan Bisnis LSPR, Bekasi, Indonesia
}

\begin{abstract}
ABSTRAK
Penelitian ini bertujuan untuk mengidentifikasi model bisnis yang digunakan oleh bisnis kuliner Bekasi Salaku dengan menggunakan business model canvas. Identifikasi dilakukan dalam 9 elemen dalam business model canvas yaitu customer segments, value proposition, channels, customer relationship, revenue streams, key resources, key activities, key partnership, dan cost structure. Penelitian ini menggunakan pendekatan kualitatif dan metode penelitian ini adalah studi kasus. Pengumpulan data primer pada penelitian ini dilakukan yaitu dengan menggunakan wawancara. Hasil penelitian yang ditemukan ialah belum adanya perencanaan Business Model Canvas yang memenuhi 9 elemen model bisnis, oleh karena itu peneliti membantu membuatkan atau merencanakan usaha kuliner khas Bekasi Salaku ke dalam 9 elemen model bisnis. Setelah merancang dari 9 elemen model bisnis Salaku miliki maka hasil simpulan dan saran yang dapat diberikan yaitu, Salaku perlu membuat strategi marketing yang lebih gencar dan menarik untuk memasarkan produk yang spesifik kepada pasar yang potensial. Strategi marketing yang lebih gencar seperti membuat suatu jadwal posting Sosial Media dalam satu timetable lalu bekerja sama dengan banyak Lembaga terkait seperti Dinas Pariwisata daerah, lalu memasarkan produk yang menarik yaitu membuat design postingan sosial media yang lebih atraktif dari warna dan angle foto lalu mengemas produk yang sesuai pada tren saat ini.
\end{abstract}

Kata kunci: perencanaan; analisis SWOT; model bisnis; business model canvas

\begin{abstract}
This study aims to identify the business model used by the Bekasi Salaku culinary business by using the business model canvas. Identification is carried out in 9 elements in the business model canvas, namely customer segments, value proposition, channels, customer relationships, revenue streams, key resources, key activities, key partnerships, and cost structure. This research uses a qualitative approach and the research method is a case study. Primary data collection in this study was carried out by using interviews. The results of the research found are that there is no Business Model Canvas planning that meets the 9 elements of the business model, therefore the researcher helps to develop or plan a culinary business typical of Bekasi Salaku into g elements of a business model. After designing the 9 elements of Salaku's business model, the conclusions and suggestions that can be given are, Salaku needs to create a more aggressive and attractive marketing strategy to market specific products to potential markets. A more aggressive marketing strategy such as making a schedule for posting Social Media in time table and then collaborating with many related institutions such as the regional Tourism Office, then marketing interesting products, namely making social media post designs that are more attractive from colors and photo angles and then packaging the product. according to the current trend.
\end{abstract}

Keywords: planning; SWOT analysis; business model; business model canvas 


\section{PENDAHULUAN}

Bisnis kuliner merupakan suatu lahan bisnis yang tergolong sangat menguntungkan. Sebagai salah satu pendukung ekonomi kreatif, bisnis kuliner kini kian menjamur. Kontribusi bisnis kuliner dalam pariwisata memberikan dampak positif bagi perekonomian lokal, nasional dan regional. Salah satu bisnis kuliner yang membantu sektor pariwisata adalah keberadaan oleholeh khas di setiap destinasi yang ada di Indonesia. Membeli oleh-oleh merupakan salah satu kebiasaan wisatawan saat mengunjungi suatu destinasi. Cita rasa khas makanan yang menjadi oleh-oleh mampu membangun daya tarik bagi wisatawan selain keindahan destinasi wisata. Oleh karena itu, penting untuk mengembangkan potensi oleh-oleh khas sebagai bisnis kuliner yang menopang kemajuan industri pariwisata.

Bekasi merupakan salah satu kota dengan populasi yang padat penduduk yang berada di dekat Kota Jakarta. Bekasi sering dikenal sebagai kota Industri dan kota urban, namun saat ini Bekasi juga mengembangkan potensi sebagai destinasi wisata. Beberapa destinasi wisata di Bekasi yang menarik seperti Wisata Alam Kota Bambu, Situ Rawa Pulo, Curug Parigi atau juga destinasi wisata modern seperti Trans Snow World Bekasi. Selain itu Bekasi juga menyediakan berbagai macam kuliner yang tak kalah menarik untuk dicoba. Kuliner Bekasi secara harafiah didominasi dengan kuliner Betawi dan sangat mudah ditemukan disudut kota. Beberapa makanan khas kuliner Bekasi yang menjadi oleh-oleh khas Bekasi seperti kue biji ketapang, kue kembang goyang, kue akar, dan bolu batik. Potensi makanan ringan sebagai oleh-oleh khas Bekasi masih terbuka untuk dikembangkan baik dalam mendukung sektor pariwisata maupun bisnis kuliner.

Berdasarkan data dari Diskominfostandi Kota Bekasi (2020) mengenai Usaha Mikro Kecil Menengah yang bersertifikat halal 2020, Salaku merupakan salah satu dari 150 UMKM bisnis kuliner Bekasi yang bersertifikat halal. Salaku merupakan bisnis kuliner Bekasi yang menyediakan produk makanan olahan dari buah salak. Berbagai hasil makanan dan minuman yang dihasilkan dari produk olahan buah salak diantaranya kue brownies, keripik salak, pie susu salak, bolu lapis salak, kukis salak, sambal salak, asinan salak, kerupuk salak, teh dan kopi salak.

Pertumbuhan bisnis kuliner bisa dikatakan mengalami peningkatan pada tiap tahunnya, pertumbuhan tersebut menjadikan sebuah persaingan dalam suatu bisnis ini menjadi kian ketat. Oleh sebab itu dengan tingginya tingkat persaingan bisnis yang semakin ketat, para pelaku bisnis harus menciptakan strategi dan inovasi yang baru agar mampu bersaing dan berkembang di era yang kompetitif ini. Akan tetapi, membuat strategi dan inovasi saja tidaklah cukup, para pelaku bisnis wajib memahami dan membuat suatu dasar atau pondasi model bisnis yang sangat kuat.

Model bisnis memaparkan pemikiran awal tentang bagaimana suatu organisasi menciptakan, memberikan, dan menyampaikan nilai kepada pasar sasaran yang dituju (Osterwalder \& Pigneur, 2010). Sebuah model bisnis dijelaskan secara detail melalui sembilan elemen penting yang menunjukkan bagaimana perusahaan secara nyata bertujuan menghasilkan keuntungan yang disebut business model canvas.

Business model canvas terdiri dari 9 elemen, yaitu (1) customer segments yaitu pasar sasaran, dapat berupa individu, komunitas atau organisasi yang ingin dijangkau perusahaan; 
(2) value propositions yaitu nilai yang ingin diberikan perusahaan kepada konsumen; (3) channels yaitu cara atau teknik perusahaan untuk berkomunikasi dengan konsumen; (4) customer relationships yaitu bagaimana manajemen hubungan antara perusahaan dengan konsumen; (5) revenue streams yaitu pendapatan yang diperoleh perusahaan; (6) key resources yaitu aset penting dan utama baik yang bersifat tangible dan intangible yang dimiliki perusahaan untuk menjalankan usahanya guna mencapai tujuan; (7) key activities yaitu kegiatan utama perusahaan yang mendukung proses layanan dan penciptaan produk; (8) key partnerships yaitu bagaimana pemilihan mitra utama yang memiliki peranan bagi perkembangan dan kemajuan perusahaan, dan (9) cost structure yaitu biaya yang dikeluarkan perusahaan untuk melakukan operasional. (Osterwalder \& Pigneur, 2010). Berdasarkan paparan diatas, maka tujuan penelitian ini adalah evaluasi dan perancangan model bisnis pada bisnis kuliner oleh-oleh khas Bekasi Salaku dengan menggunakan Business Model Canvas agar mampu bersaing di tengah ketatnya kompetisi bisnis makanan ringan/snack.

\section{Strategi Bisnis}

Perkembangan dunia usaha pada saat ini kian kompetitif, yang mana membuat para pelaku bisnis berlomba-lomba membuat suatu inovasi dan pengembangan baik pada produk yang dimiliki maupun pelayanan untuk para calon pembeli maupun pelanggannya. Inovasi dan pengembangan tersebut tak lepas dengan sebutan strategi, menurut David (2009), Strategi adalah sarana bersama dengan tujuan jangka panjang hendak dicapai, aksi potensial yang membutuhkan keputusan manajemen puncak dan sumber daya perusahaan dalam jumlah yang besar. Strategi adalah sebuah tindakan yang memiliki kekuatan, yang dibutuhkan untuk pengambilan keputusan di manajemen puncak. Strategi memiliki konsekuensi yang multifungsi dan multidimensi serta perlu mempertimbangkan faktor-faktor eksternal dan internal yang dihadapi perusahaan (David, 2013).

Tak jarang para pelaku usaha selalu membuat suatu perencanaan terlebih dahulu sebelum memulai bisnis usahanya dengan membuat strategi bisnis. Menurut David (2009), strategi bisnis adalah alat untuk mencapai tujuan jangka panjang. Sebuah perusahaan harus berjuang mencapai keuntungan kompetitif secara berkelanjutan, berupa (1) terus beradaptasi untuk berubah dalam trend eksternal dan kapasitas internal, kemampuan dan sumberdaya; dan (2) perencaan efektif, implementasi dan evaluasi strategi yang berperan besar (David, 2009).

\section{Business Model Canvas}

Salah satu strategi yang sering digunakan bagi para pelaku bisnis yaitu business model canvas. Osterwalder dan Pigneur, (2012) mengemukakan Business Model Canvas merupakan salah satu alat strategi yang digunakan untuk mendeskripsikan sebuah model bisnis dan menggambarkan dasar pemikiran tentang bagaimana organisasi menciptakan, memberikan, dan menangkap nilai. Business Model Canvas merupakan suatu alat untuk membantu pengusaha melihat lebih akurat usaha bisnis yang sedang atau akan dijalani. Business Model Canvas akan memudahkan pebisnis untuk membangun dan mengembangkan bisnis atau perusahaan yang dijalankan. Business Model Canvas memiliki terdiri 9 elemen utama yang terintegrasi satu dengan yang lain sehingga menjadi kesatuan business plan yang nyata dan dapat dijalankan. Sembilan elemen tersebut adalah: (1) Customer Segments (Segmen Pelanggan); (2) Value Propositions (proposisi nilai); (3) Channel (Saluran); (4) Customer Relationships (Hubungan Pelanggan); (5) Revenue Streams (Arus Pendapatan); (6) Key 
Resources (Sumber Daya Utama); (7) Key Activities (Aktivitas Kunci); (8) Key Partnerships (Kemitran Utama); dan (9) Cost Structure (Struktur Biaya).

\section{METODE PENELITIAN}

Penelitian ini menggunakan pendekatan kualitatif dengan jenis penelitian deskriptif yang bertujuan untuk memaparkan dan menganalisis business model canvas pada bisnis kuliner Salaku Bekasi.

Metode penelitian yang digunakan adalah metode studi kasus. Menurut Robert K. Yin (2014) adalah suatu metode atau cara yang menekankan pada penelitian yang mana memiliki unsur-unsur how dan why. Bisa dikatakan metode studi kasus ini dapat berguna dalam menjelaskan sesuatu yang komprehensif yang ada kaitannya dengan aspek seseorang, organisasi, program, kelompok maupun masyarakat yang akan diteliti yang mana dapat ditelaah lebih dalam dalam kurun waktu tertentu.

Metode studi kasus merupakan metode yang melakukan penyelidikan mendalam sehingga dapat mengetahui secara lengkap gambaran mengenai keadaan perusahaan tersebut. Tujuan dari studi kasus yaitu dapat mengantarkan peneliti untuk memasuki unit-unit sosial seperti individu, kelompok, lembaga atau komunitas.

Subjek dalam penelitian ini adalah individu yang terlibat dalam menjalankan aktivitas pada bisnis kuliner Salaku Bekasi yaitu pemilik dan staf bisnis kuliner Salaku Bekasi. Objek penelitian ini adalah evaluasi model bisnis pada bisnis kuliner Salaku Bekasi dengan menggunakan pendekatan 9 elemen dalam business model canvas yaitu value propositions, customer segments, channels, customer relationships, revenue streams, key sources, key activities, key partnerships, dan cost structure.

Penelitian ini menggunakan sumber data primer yang diperoleh secara langsung dari hasil wawancara dengan subjek penelitian. Data primer dalam peneltian ini fokus pada dasar pemikiran dan pertimbangan pemilik bisnis kuliner Salaku Bekasi dalam membangun business model canvas.

Penelitian ini menggunakan suatu Teknik dalam memngumpulkan data, dimana Teknik yang digunakan oleh peneliti adalah metode wawancara. Menurut Esterberg dan Sugiyono (Sugiyono, 2016) metode wawancara adalah suatu pertemuan antara dua orang atau lebih guna untuk bertukar informasi dan ide melalui instrument tanya jawab, oleh sebab itu dapat dikontruksikan makna dalam suatu topik tertentu.

Metode wawancara yang akan digunakan oleh peneliti adalah wawancara semi terstruktur yang mana wawancara yang sedang dilakukan saat melakukan penelitian kemungkinan berubah sesuai dengan kondisi dan jawaban yang diberikan oleh narasumber.

Pada teknik analisis data, peneliti memakai konsep model analisis data dari Milles, Huberman, dan Sugiyono (dalam Sugiyono, 2016) dimana dalam teori tersebut mengemukakan 3 langkah, yaitu (1) Data Reduction, sebuah langkah awal ialah merangkum, memilih hal-hal yang utama dan fokus pada sesuatu yang dianggap penting. Ketika menemukan data-data yang tidak sesuai maka, data tersebut akan disortir atau direduksi. 
Apabila data sudah direduksi maka, peneliti dapat lebih mudah mendapatkan informasi yang lebih fokus dan terarah pada topik penelitian; (2) Data Display, setelah itu data display merupakan langkah kedua yang mana setelah melakukan reduksi data ialah menyajikan data. Data tersebut disajikan dalam bentuk tabel, pie chart, grafik dan bentuk lain yang sejenis; (3) Conclusion Drawing / verification, adalah langkah akhir dalam teknik analisa kualitatif ini yaitu melakukan penarikan kesimpulan dan verifikasi penelitian. Pada kesimpulan awal apabila tidak ditemukan bukti yang kuat atau valid maka kesimpulan tersebut bersifat sementara, namun jika ditemukan bukti-bukti yang valid dalam penelitian maka kesimpulan tersebut dapat dikemukakan secara terpercaya.

\section{HASIL DAN PEMBAHASAN}

\section{Gambaran Umum UMKM Salaku}

Salaku merupakan salah satu kuliner oleh-oleh khas Bekasi yang mana produk unggulan yang dimiliki adalah olahan buah salak. Melalui tagline "cara enak makan salak" diharapkan agar masyarakat dapat mengonsumsi buah salak melalui produk olahan makanan dan minuman yang beraneka ragam. Ide ini berawal dari pemilik Salaku yaitu Ibu Shelly memiliki anak yang malas membuka kulit buah salak yang tergolong tajam. Kulit buah salak yang mudah sekali melukai tangan dan jari para penikmat buah ini. Namun hal ini menjadikan terbentuknya ide awal dan konsep dari usaha oleh-oleh khas Bekasi ini. Olahan buah salak dibuat beraneka ragam, dari produk makanan seperti brownies, bolu, kerupuk, keripik, sambal salak, asinan, pie susu, kukis mapun produk minuman seperti sari buah salak. Selain itu, selain buah dari salaknya tersendiri, kulit dan bijinya pun diolah menjadi komoditas teh dan kopi. Teh dan kopi ini berangkat dari temuan yang mana pemilik usaha ingin mengurangi limbah atau sisa olahan buah salak, bisa disebut pula dengan istilah zero waste. Oleh sebab itu, biji dan kulit buah salak tersebut melalui proses penelitian yang dalam, bisa tercipta suatu terobosan yang sangat menarik. Hal ini sudah diuji coba melalui tim kampus Institut Pertanian Bogor bahwasanya semua bagian buah salak sangat bergizi dan bermanfaat serta aman dikonsumsi. Kuliner khas Bekasi Salaku membuka gerai di dalam rumah yang dimiliki pemilik usaha. Menggunakan konsep bisnis keluarga, pemilik usaha Salaku memanfaatkan anggota keluarga sebagai karyawan atau pengurus usaha Salaku. Salaku telah mendapatkan beberapa penghargaan bergengsi, salah satunya pernah menjadi "TOP 20 The Big Start Indonesia Season 3" oleh Blibli.com dan yang terakhir menjadi juara pertama di ajang kompetensi UMKM Terbaik "LSPR Culinary Entrepreneur Award 2021". Berikut adalah logo Salaku dan foto produk yang dimiliki, foto tersebut dapat dilihat dalam media sosial Instagram yang Salaku miliki yaitu @salakuolahansalak.

Gambar 1. Logo Salaku

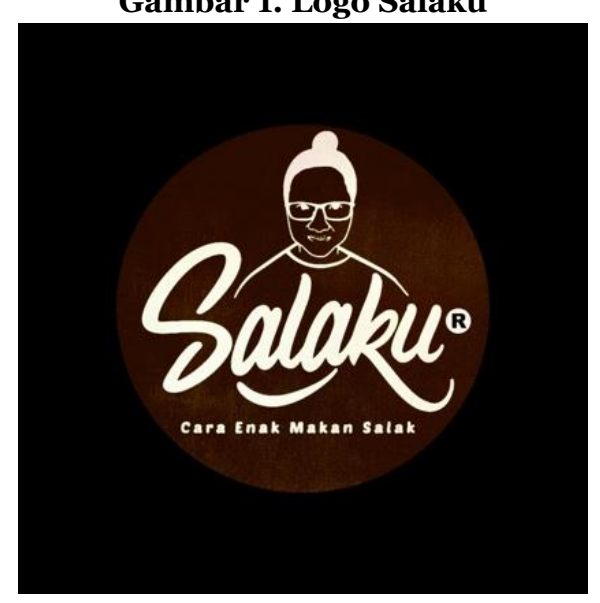




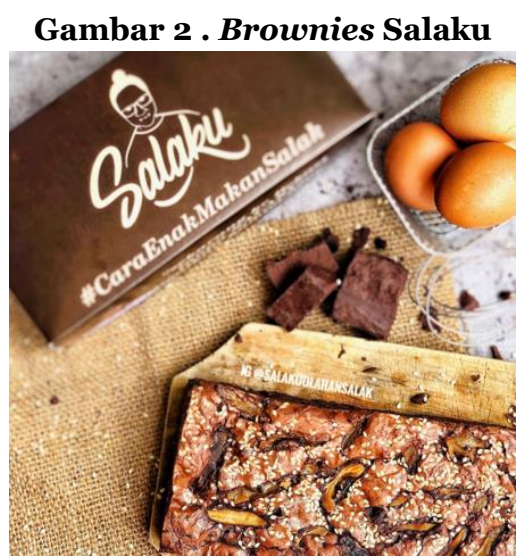

Sumber: Instagram SALAKU (2021)

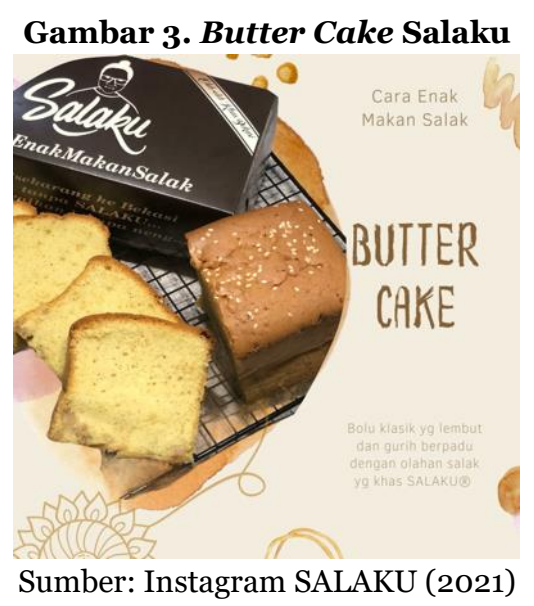

Gambar 4. Kue Kering Salak (Kuklak)

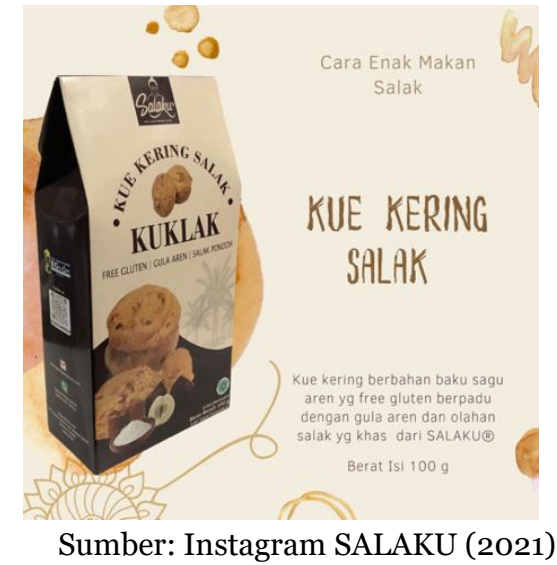

Harga yang dijual pun cukup beragam, dimulai dari Rp 15.000 - Rp 55.000. Adapun paket hampers yang dibuat ketika hari-hari besar layaknya Lebaran dan Natal hingga tahun baru, yang mana harga hampers dimulai dari Rp 55.000 sesuai permintaan. Pencapaian tersebut yang menjadikan Salaku tidak pernah berhenti berinovasi dan berkreasi terutama pada masa pandemi ini.

\section{Business Model Canvas UMKM Salaku}

Customer segment adalah individu, kelompok atau organisasi yang akan dijangkau atau dituju oleh perusahaan. Sasaran konsumen pada bisnis kuliner Bekasi Salaku ialah kaum urban yaitu 
seseorang atau pendatang yang berdomisili di Bekasi yang ingin pulang kampung ke daerah asalnya dengan membawa oleh-oleh. Selain itu, para pekerja yang memiliki pekerjaan dan tinggal sementara di Bekasi. Karena kota Bekasi memiliki Kawasan industri, banyak pabrikpabrik besar dari merek ternama baik dalam negeri maupun luar negeri.

Value Proposition merupakan nilai keunggulan dari suatu produk atau jasa yang membedakan dengan pesaing dan memberikan nilai lebih kepada konsumen yang dituju. Value proposition merupakan alasan mengapa sebuah pasar yang dituju memilih produk tersebut. Value proposition yang dimiliki Salaku ialah Salaku merupakan pioneer atau pencetus dari sebuah bisnis makanan yang menggunakan buah salak sebagai bahan dasar dan menggunakan semua bagian salak sebagai komoditi utama. Salaku merupakan satu-satunya bisnis kuliner di Indonesia yang mengolah biji, buah dan kulit salak menjadi berbagai produk makanan dan minuman. Produk-produk tersebut ialah kue brownies, keripik, sambal, kukis, asinan, kerupuk, bolu keju, pie susu, minuman sari buah, kopi, dan teh.

Channels adalah bagaimana cara perusahaan untuk berkomunikasi dengan pelanggan untuk menyampaikan proposisi nilai sehingga pelanggan dapat menerima dan memahami dengan baik nilai keunggulan dari produk atau jasa yang ditawarkan. Salaku menjual produkproduknya langsung dari rumah pemiliknya sendiri dan tidak memiliki store tersendiri, dikarenakan Salaku ingin mendapatkan market-nya terlebih dahulu, apabila Salaku sudah memiliki market khusus maka tidak menutup kemungkinan strategi selanjutnya adalah membuka gerai/toko tersendiri. Selain itu Salaku memperkenalkan produknya melalui media online yaitu seperti Instagram, Facebook, WhatsApp. Salaku juga menjual produknya di GoFood, GrabFood dan Shopee Food yang mana dapat menjangkau pasar yang lebih luas dengan biaya promosi yang relatif terjangkau.

Customer relationship merupakan hubungan perusahaan dengan pelanggan yang menggunakan produk dari perusahaan. Penting bagi perusahaan untuk mengelola hubungan dan interaksi dengan konsumen. Hal ini bertujuan untuk membangun loyalitas. Usaha kuliner Bekasi Salaku menjalin hubungan dengan pelanggannya melalui direct message Instagram dan WhatsApp akan tetapi hanya sebagai tempat berjualan saja atau menawarkan produk apabila ada pelanggan yang bertanya. Bisa dikatakan bahwasanya Salaku tidak terlalu ahli dalam bidang menjalin komunikasi dan mempertahankan pelanggan. Salaku hanya menggunakan platform tersebut hanya untuk memberikan list harga apabila ada yang bertanya maupun mengunggah promo terkini.

Revenue stream adalah pendapatan atau keuntungan yang didapatkan oleh perusahaan. Revenue streams memiliki mekanisme nilai yang berbeda seperti penetapan harga tetap, tawar menawar, lelang, bergantung pada pasar, bergantung pada volume, atau pengelolaan hasil. Pendapatan yang didapat dari bisnis oleh-oleh Salaku ialah produk-produk yang dimiliki dan ditawarkan kepada pasar yang dimiliki melalui online maupun offline. Selain itu bisnis Salaku juga memiliki pendapatan lain yaitu menerima pesanan dari berbagai macam acara seperti pernikahan maupun pertemuan-pertemuan lain seperti contoh yang mana Salaku pernah membuat pesanan untuk sebuah acara dengan membuat menu rice box yang komoditas utamanya nasi ayam dengan menggunakan sambal olahan dari salak. Salaku juga sering menerima pendapatan yang besar dari sebuah pameran-pameran kuliner di Jakarta. Dari pameran tersebut bisa dikatakan, sebuah media yang bisa memperkenalkan bisnis usaha Salaku ke pangsa pasar yang baru. Berdasarkan wawancara, produk Salaku yang paling 
banyak laku di pasaran yaitu olahan kue brownies dan bolunya. Ada pun, di saat pameran, produk sambal yang terbuat dari salak, sangat menarik perhatian sehingga setiap pameran berlangsung produk sambal paling laris. Teh dan kopinya pun tidak kalah bersaing, yang mana hingga saat ini akan ditargetkan bisa menjadi komoditas ekspor utama dari produk Salaku.

Key resources yaitu berupa aset terpenting yang dibutuhkan oleh perusahaan sehingga model bisnis dapat berjalan dengan baik. Key resources dapat berupa fisik, keuangan, intelektual, atau manusia. Sumber daya kunci ini dapat dimiliki atau disewa oleh perusahaan atau diakuisisi dari key partner. Sumber daya fisik yang dimilik Salaku yaitu ruang dapur yang dijadikan sebagai media untuk mengolah bahan dasar buah salak menjadi produk-produk yang bernilai, telepon genggam sebagai media memasarkan dan menjual produk-produk Salaku, peralatan dan perlengkapan dalam pengolahan seperti mesin kopi, oven, stove, dan lain-lain. Sumber daya manusia yang dimiliki Salaku ialah berjumlah 5 orang yang mana masih dalam ikatan keluarga inti, yaitu suami, istri dan anak. Tugas dari 5 anggota keluarga yaitu, ada yang bertugas mengolah produk baik makanan dan minuman sekitar 2-3 orang, lalu anggota yang lain bertugas menjalankan sosial media dan strategi marketing lain. Apabila Salaku memiliki pesanan pada acara-acara besar, biasanya Salaku mencari sumber daya manusia yang lebih banyak seperti saudara dan tetangga dekat yang mana sudah dilakukan training agar dapat mengolah produk-produk Salaku. Sumber daya intelektual yang dimilik salaku adalah SOP dan resep rahasia dari berbagai produk yang dimiliki. Resep tersebut dibuat langsung oleh pemilik bisnis usaha Salaku melalui uji coba dan penelitian yang mendalam.

Key Activities yaitu kegiatan yang harus dilakukan perusahaan dalam membuat model bisnis. Sama halnya dengan key resources, key activities diwajibkan untuk membuat serta menawarkan proposisi nilai, menjangkau pasar, menjaga hubungan pelanggan, dan mendapatkan pendapatan (Osterwalder \& Pigneur, 2010). Aktivitas utama dari bisnis kuliner Salaku adalah penjualan produk-produk yang dimiliki melalui offline maupun online. Selain itu Salaku juga melakukan pemesanan dalam porsi besar untuk acara-acara tertentu seperti wedding, meeting, sampai acara keluarga. Salaku juga sering ikut serta dalam acara tahunan seperti pameran yang ada di kota-kota besar seperti Jakarta dan Surabaya. Pameran tersebut menjadi ajang untuk menjual produk maupun memperkenalkan produk ke market yang lebih luas dan baru. Kompetisi dan lomba kuliner pun, tidak pernah terlewati, baru-baru ini Salaku menjadi juara pertama dalam kompetisi UMKM Jabodetabek, sebagai UMKM Kuliner terbaik.

Key Partnership adalah jaringan yang dimiliki oleh perusahaan yang berhubungan dengan pemasuk bahan baku dan mitra bisnis dari perusahaan sehingga dapat membuat model bisnis berjalan. Perusahaan menciptakan aliansi untuk mengoptimalkan model bisnis mereka, mengurangi resiko, dan akuisisi sumber daya (Osterwalder \& Pigneur, 2010). Partner yang dimiliki Salaku adalah supplier Salak di Bekasi, dimana supplier atau pemasok tersebut sudah lama menjadi mitra utama bisnis usaha Salaku. Selain itu Salaku menjalin keanggotaan pada UMKM Kota Bekasi yang mana berada di bawah langsung Pemerintahan Kota Bekasi. Pada keanggotaan tersebut, apabila Kota Bekasi memiliki acara-acara besar, UMKM terbaik akan dipilih untuk mengisi di acara atau kegiatan tersebut dan Salaku sering terpilih untuk mengisi acara sebagai narasumber. Hal inilah yang membuka peluang Salaku untuk mengembangkan bisnisnya menjadi lebih baik. 
Cost Structure merupakan semua biaya yang dikeluarkan perusahaan yang digunakan untuk mengoperasikan model bisnis. Berdasarkan hasil wawancara dengan pemilik bisnis usaha kuliner dan oleh-oleh Salaku, dapat dideskripsikan bahwa biaya yang dikeluarkan terdiri dari 2 macam yaitu fixed cost (biaya tetap) dan variable cost (biaya variabel). Biaya tetap yang dimiliki Salaku adalah biaya listrik dan air penggunaan peralatan dan perlengkapan dalam pengolahan produk. Biaya variabel yang dimiliki adalah pembelian bahan, perlengkapan dan peralatan, dan biaya gaji.

Tabel 1. Rancangan 9 Elemen Bisnis Model Salaku

\begin{tabular}{|c|c|c|c|c|c|}
\hline $\begin{array}{l}\text { 8. Key } \\
\text { Partners }\end{array}$ & $\begin{array}{l}\text { 7. Key } \\
\text { Activities }\end{array}$ & \multicolumn{2}{|c|}{$\begin{array}{l}\text { 2.Value } \\
\text { Propositions }\end{array}$} & $\begin{array}{l}\text { 4.Customer } \\
\text { Relationships }\end{array}$ & $\begin{array}{l}\text { 1. Customer } \\
\text { Segments }\end{array}$ \\
\hline \multirow[t]{3}{*}{$\begin{array}{l}\text { Supplier Salak } \\
\text { Pemkot Bekasi }\end{array}$} & $\begin{array}{l}\text { - Pameran } \\
\text { - Online } \\
\text { - Offline }\end{array}$ & \multirow{3}{*}{\multicolumn{2}{|c|}{$\begin{array}{l}\text { - Single Brand } \\
\text { - Mengolah } \\
\text { bahan salak } \\
\text { dari biji, } \\
\text { buah, kulit, } \\
\text { ampas. } \\
\text { - Pioneer di } \\
\text { Indonesia } \\
\text { dalam } \\
\text { mengolah } \\
\text { Salak } \\
\text { - Inovasi } \\
\text { Produk } \\
\text { - Produk } \\
\text { Olahannya } \\
\text { banyak: } \\
\text { Keripik, } \\
\text { sambal, kopi, } \\
\text { the, } \\
\text { Brownies, } \\
\text { dll }\end{array}$}} & $\begin{array}{l}\text { Tidak ada } \\
\text { program } \\
\text { khusus dalam } \\
\text { menjalin } \\
\text { hubungan } \\
\text { dengan } \\
\text { customer, baik } \\
\text { calon dan } \\
\text { repeater. }\end{array}$ & \multirow{3}{*}{$\begin{array}{l}\text { - Orang yang } \\
\text { berdomisili di } \\
\text { Bekasi yang ingin } \\
\text { pulang kampung } \\
\text { ke daerah asalnya } \\
\text { dengan } \\
\text { membawa oleh- } \\
\text { oleh. } \\
\text { - Para Pekerja, } \\
\text { yaitu pendatang } \\
\text { yang bekerja di } \\
\text { Bekasi (Kawasan } \\
\text { industri), Pabrik, } \\
\text { Pertokoan, dll. } \\
\text { - Kaum Urban: } \\
\text { kaum pendatang } \\
\text { Ketika pulang, } \\
\text { membawa oleh2 } \\
\text { - Ingin masuk } \\
\text { pasar Indonesia } \\
\text { Retail, missal } \\
\text { Pasar produsen } \\
\text { Bekasi. } \\
\text { - Jangka Panjang: } \\
\text { Masuk pasar } \\
\text { INTL, Kopi dan } \\
\text { Tehnya. }\end{array}$} \\
\hline & $\begin{array}{l}\text { 6. Key } \\
\text { Resources }\end{array}$ & & & 3. Channels & \\
\hline & $\begin{array}{l}\text { - } \text { Fasilitas } \\
\text { Rumah } \\
\text { - Equipment }\end{array}$ & & & $\begin{array}{l}\text { - Offline: rumah } \\
\text { - GoFood } \\
\text { - GrabFood } \\
\text { - Shoppe food } \\
\text { - WhatsApp } \\
\text { - Instagram } \\
\text { - Pameran }\end{array}$ & \\
\hline \multicolumn{3}{|c|}{ 9. Cost Structure } & \multicolumn{3}{|c|}{ 5. Revenue Streams } \\
\hline \multicolumn{3}{|c|}{$\begin{array}{l}\text { Biaya fix: Listrik dan air } \\
\text { Biaya Variabel: Bahan, Gaji, peralatan } \\
\text { dan perlengkapan }\end{array}$} & - & $\begin{array}{l}\text { Pameran } \\
\text { Online } \\
\text { Offline }\end{array}$ & \\
\hline
\end{tabular}

Sumber: Data Olahan Penulis (2021)

Berdasarkan wawancara terhadap narasumber yaitu pemilik bisnis kuliner Salaku mengenai 9 elemen business model canvas, setelah itu akan dilakukan analisis dengan menggunakan analisis SWOT pada setiap elemennya. Melalui analisis SWOT, pelaku usaha bisa mengetahui posisi perusahaan atau bisnis mereka ada berada di posisi apa dan di mana serta apa yang 
harus dilakukan untuk selanjutnya. Menurut Freddy (2013), analisis SWOT adalah analisa yang didasarkan pada logika yang dapat memaksimalkan kekuatan (Strength) dan peluang (Opportunity), namun secara bersamaan dapat meminimalkan kelemahan (Weakness) dan ancaman (Threats). Menurut Galavan (2014), analisis SWOT (Strength, Weakness, Opportunity, dan Threat) yaitu analisis untuk mendapatkan strategi yang berguna atau efektif yang diterapkan sesuai pasar dan keadaan publik saat itu, peluang (opportunity) dan ancaman (threat) dipakai untuk mengetahui lingkungan luar atau eksternal kemudian kekuatan (strength) dan kelemahan (weakness) yang didapatkan melalui analisis dalam perusahaan atau internal. Berdasarkan definisi di atas dapat disimpulkan bahwa analisis SWOT, yaitu suatu metode untuk menggambarkan dan membandingkan bagaimana kondisi dan cara untuk mengevaluasi suatu masalah bisnis dan proyek berdasarkan faktor eksternal dan internal, yaitu Strength, Weakness, Opportunity, dan Threat. Berikut penjabaran 9 elemen business model canvas dengan menggunakan analisis SWOT:

\section{Customer Segment}

Salaku menjadi pilihan utama sebagai produk kuliner oleh-oleh di Kota Bekasi yang mana segmen pasar bagi kaum urban dengan mudah membeli produk Salaku. Kemasan yang menarik dan bahan dasar yang menyehatkan menjadi pilihan yang sangat baik sebagai buah tangan. Namun karena olahan produk dengan bahan dasar Salak, tidak semua orang menyukainya dan tidak semua orang tertarik dengan buah salak padahal olahannya sangat menarik, bisa dikatakan bahan dasar yang sudah sangat spesifik. Peluang yang dimiliki adalah, dimasa pandemi ini masyarakat beralih ke makanan sehat yang mana sangat sesuai dengan konsep Salaku lalu semua produk Salaku Sebagian besar dijual secara online yang mana bisa menjangkau luar Jabodetabek, luar pulau Jawa, dan sedang merencanakan untuk meraih pangsa pasar luar negeri serta bisa menjadi brand awareness keberagaman produk kuliner di dunia pariwisata. Tantangan yang dilalui yaitu produk makanan sehat dan bisnis kuliner dengan kategori oleh-oleh kian menjamur, yang membuat Salaku harus semakin inovatif dan berkembang dalam memasarkan produk, lalu pasar Indonesia yang belum aware dengan makanan dengan bahan dasar yang menyehatkan.

\section{Value Propositions}

Produk Salaku memiliki karakteristik yang sangat kuat yaitu komoditas buah salak dengan memanfaatkan biji, buah, dan kulit salak menjadi suatu makanan dan minuman selain itu pencetus dan pioneer pada bisnis usaha kuliner dengan menghasilkan beragam makanan dan minuman olahan salak. Hal-hal tersebut menjadi kekuatan pada produk Salaku. Namun kelemahannya adalah produk tersebut sangat spesifik, sehingga pelaku bisnis perlu mencari cara dalam memperkenalkan produk-produk Salaku lebih luas lagi. Peluang yang bisa diambil yaitu dengan karakteristik tersebut bisa menjadi peluang baru dan menciptakan pangsa baru dan tersendiri. Tantangannya adalah apabila produk-produk Salaku ini menjadi lebih terkenal maka ada kemungkinan bisa ditiru dan dimodifikasi oleh seseorang.

\section{Channels}

Media online yang dimiliki salah satunya Instagram memiliki konten dan foto yang sangat menarik, desain yang digunakan juga sesuai dengan konsep Salaku. Namun apabila dilihat pada setiap konten, kurang memiliki storytelling, jadi terlihat hanya berjualan produk saja, selain itu Salaku tidak menggunakan endorser dalam memasarkan produknya. Melalui media online kesempatan meraih pasar yang lebih luas dan tak terbatas menjadi peluang bagi Salaku, tidak hanya Jabodetabek namun bisa luar pulau Jawa maupun luar negeri. Banyak bisnis 
kuliner membuat konten dan marketing yang menarik pada media sosial yang dimiliki menjadi tantangan yang sangat besar bagi Salaku walaupun produk yang ditawarkan sangat unik dan lain dari yang lain tetap saja tools yang digunakan menjadi media yang menentukan bagaimana pasar bisa mendengar produk tersebut.

\section{Customer Relationship}

Salaku sangat intens menawarkan produk-produknya melalui WhatsApp Story yang mana langsung bisa dilihat oleh para pelanggannya, namun hanya sebatas mengepos produk dan tidak menanyakan kembali bagaimana produk yang telah dibeli dan dikonsumsi serta tidak memelihara pelanggan dengan menawarkan produk baru dan pemberian diskon atau promosi. Melalui media online, membuka peluang untuk lebih mudah menjalin hubungan dengan para pelanggan. Kebutuhan pasar yang lebih kompleks membuat pelayanan yang ditawarkan harus lebih personal.

\section{Revenue Streams}

Memiliki beragam produk membuat Salaku menghasilkan pendapatan melalui pasar yang lebih luas dan tidak hanya dari penjualan secara offline dan online serta dapat mengisi di dalam berbagai acara dan pameran. Namun kurangnya Salaku dalam menjalin hubungan terhadap para pelanggan tetapnya maka dapat mempengaruhi pendapatan yang seharusnya bisa bertahan. Semua media offline dan online yang dimiliki serta keberagaman produk dapat menjadi sumber pendapatan yang sangat baik, memiliki karakteristik produk yang sangat kuat mampu menjadi peluang bagi Salaku. Hantaman pandemi menjadi tantangan bagi Salaku di mana Sebagian besar seseorang mengurangi daya beli, namun bisa menjadi peluang apabila melalui media online.

\section{Key Resources}

Resep yang unik dan beragam serta karyawan inti berasal dari keluarga menjadikan kekuatan Salaku, namun akan menjadi kelemahan apabila memiliki kegiatan wedding dan catering dalam jumlah besar dan perlu mencari sumber daya manusia dari luar yang mana bisa mengurangi kualitas produk Salaku, lalu penggunaan listrik dan air yang menjadi satu dari rumah pribadi menjadi kelemahan Salaku. Peluang Salaku yang menjual produk secara offline melalui rumah pribadi menjadikan Salaku tidak perlu membayar uang sewa tempat atau Gedung. Apabila permintaan makin tinggi, keterbatasan tempat dan sumber daya manusia menjadi tantangan untuk menghasilkan produk yang berkualitas selain itu usaha rumahan yang tidak terstandar juga mempengaruhi hasil dari produk tersebut.

\section{Key Activities}

Aktivitas yang dilakukan oleh Salaku menjadi kekuatan yang sangat baik yaitu menjual produk secara online dan offline, mengikuti pameran, dan berbagai kompetisi. Namun dari hal tersebut, Salaku tidak memiliki sumber daya yang mumpuni dalam menjalankan aktivitas online seperti konten-konten di platform sosial media. Peluang yang dimiliki adalah Salaku sedang melakukan pengurusan dokumen agar dapat melakukan ekspor barang ke negara tetangga dan media online. Tantangannya adalah dimana pemerintah akan berencana membuat kebijakan pajak bagi pelaku bisnis online.

\section{Key Partnership}

Memiliki pemasok tetap dan terjangkau serta kerjasama dalam naungan Pemerintahan Kota Bekasi menjadi kekuatan Salaku dalam menjalankan bisnisnya. Namun, Salaku memiliki 
pemasok buah salak yang sangat sedikit. Keunikan produk, dapat memberikan peluang untuk bekerja sama dengan lembaga-lembaga lain dalam ajang memberikan sponsorship maupun kolaborasi. Namun karena komoditas salak hanya sedikit yang menjual, maka dari itu apabila terjadi hal-hal yang tidak diinginkan seperti musim yang tidak baik maka akan sulit mencari pemasok buah salak, serta pesaing-pesaing UMKM produk oleh-oleh lainnya yang berada dalam Pemerintahan Kota Bekasi yang semakin kompetitif.

\section{Cost Structures}

Biaya yang dikeluarkan hanya sedikit karena tergabung dalam rumah pribadi namun pembagian penggunaan menjadikan tidak stabilnya perhitungan cost untuk bisnis Salaku itu tersendiri bisa dikatakan pengeluaran antara penggunaan pribadi dan pengeluaran dalam operasional. Biaya yang digunakan lebih terkontrol karena pemilik dan operasional ikut andil langsung menjadi peluang yang baik sedangkan tantangannya ialah pajak yang dikeluarkan suatu saat harus berbeda yaitu adanya pajak izin menjalankan usaha.

Tabel 2. Perencanaan 9 Elemen Bisnis Model Salaku

\begin{tabular}{|c|c|c|c|c|}
\hline $\begin{array}{l}\text { 8. Key } \\
\text { Partners }\end{array}$ & $\begin{array}{l}\text { 7. Key } \\
\text { Activities }\end{array}$ & $\begin{array}{l}\text { 2.Value } \\
\text { Propositions }\end{array}$ & $\begin{array}{l}\text { 4.Customer } \\
\text { Relationships }\end{array}$ & $\begin{array}{l}\text { 1. Customer } \\
\text { Segments }\end{array}$ \\
\hline \multirow[t]{3}{*}{$\begin{array}{ll}\text { - } & \text { Beberapa opsi } \\
& \text { Supplier Salak } \\
\text { - } & \text { Pemkot Bekasi } \\
\text { - } & \text { Institusi } \\
\text { - } & \text { Pusat } \\
& \text { Enterprenership }\end{array}$} & $\begin{array}{l}\text { - Pameran } \\
\text { - Online } \\
\text { - Offline } \\
\text { - Kegiatan } \\
\text { Sosialisasi } \\
\text { - Celebrity } \\
\text { Endorsement }\end{array}$ & \multirow{3}{*}{$\begin{array}{l}\text { - Single Brand } \\
\text { - Mengolah } \\
\text { bahan salak } \\
\text { dari biji, buah, } \\
\text { kulit, ampas. } \\
\text { - Pioneer di } \\
\text { Indonesia } \\
\text { dalam } \\
\text { mengolah } \\
\text { Salak } \\
\text { - Inovasi } \\
\text { Produk } \\
\text { - Produk } \\
\text { Olahannya } \\
\text { banyak: } \\
\text { Keripik, } \\
\text { sambal, kopi, } \\
\text { the, Brownies, } \\
\text { dll }\end{array}$} & $\begin{array}{l}\text { a. Personal } \\
\text { experiences } \\
\text { b. Membership } \\
\text { program }\end{array}$ & \multirow{3}{*}{$\begin{array}{l}\text { - Orang yang } \\
\text { berdomisili di } \\
\text { Bekasi yang } \\
\text { ingin pulang } \\
\text { kampung ke } \\
\text { daerah asalnya } \\
\text { dengan } \\
\text { membawa oleh- } \\
\text { oleh. } \\
\text { - Para Pekerja, } \\
\text { yaitu pendatang } \\
\text { yang bekerja di } \\
\text { Bekasi } \\
\text { (Kawasan } \\
\text { industri), } \\
\text { Pabrik, } \\
\text { Pertokoan, dll. } \\
\text { - Kaum Urban: } \\
\text { kaum } \\
\text { pendatang } \\
\text { Ketika pulang, } \\
\text { membawa oleh2 } \\
\text { - Ingin masuk } \\
\text { pasar Indonesia } \\
\text { Retail, missal } \\
\text { Pasar produsen } \\
\text { Bekasi. } \\
\text { - Jangka } \\
\text { Panjang: Masuk }\end{array}$} \\
\hline & $\begin{array}{l}\text { 6. Key } \\
\text { Resources }\end{array}$ & & 3. Channels & \\
\hline & $\begin{array}{l}\text { - Fasilitas } \\
\text { Rumah } \\
\text { - Equipment }\end{array}$ & & $\begin{array}{l}\text { - Offline: rumah } \\
\text { - GoFood } \\
\text { - GrabFood } \\
\text { - Shoppe Food } \\
\text { - WhatsApp } \\
\text { - Instagram } \\
\text { - Pameran }\end{array}$ & \\
\hline
\end{tabular}




\begin{tabular}{|c|c|c|}
\hline & & $\begin{array}{l}\text { pasar INTL, } \\
\text { Kopi dan } \\
\text { Tehnya. }\end{array}$ \\
\hline 9. Cost Structure & \multicolumn{2}{|l|}{ 5. Revenue Streams } \\
\hline $\begin{array}{l}\text { Biaya fix: Listrik dan air } \\
\text { Biaya Variabel: Bahan, Gaji, peralatan dan } \\
\text { perlengkapan }\end{array}$ & $\begin{array}{ll}\text { - } & \text { Pameran } \\
\text { - } & \text { Online - Offline } \\
\text { - } & \text { Kegiatan sosialisasi }\end{array}$ & \\
\hline
\end{tabular}

Sumber: Data Olahan Penulis (2021)

\section{SIMPULAN}

Model bisnis yang dimiliki oleh UMKM Salaku berdasarkan Business Model Canvas adalah sebagai berikut yaitu Salaku memiliki segmen pasar yang sudah sangat spesifik yaitu kaum urban atau pendatang yang memiliki pekerjaan di Kota Bekasi yang mana apabila mereka balik ke daerah asalnya bisa membeli oleh-oleh atau buah tangan khas Bekasi. Produk yang unik dan berkarakter yaitu menggunakan Buah Salak sebagai bahan dasar dan komoditas utamanya. Buah Salak diolah dari biji, buah, dan kulitnya yang menghasilkan berbagai macam produk olahan seperti Brownies, Pie Susu, Bolu Keju, Kukis, Asinan, kerupuk, teh, dan kopi. Salaku menjual produknya melalui offline store dan online, media online menggunakan sosial media seperti Instagram, Facebook serta WhatsApp. Media online menjadikan Salaku dapat menembus pasar yang lebih luas. Mengenai customer relation, Salaku tidak terlalu menjadikan hal ini sebagai prioritas, jadi hanya sebatas WhatsApp Story dan Instagram Story saja. Pendapatan yang dihasilkan didapati dari penjualan beragam produk Salaku baik melalui media online dan offline. Salaku memiliki pekerja dari anggota keluarga inti saja namun apabila ada acara dalam jumlah besar, maka Salaku akan memanggil relasi terdekat untuk membantu. Membuka store offline melalui rumah pribadi yang berlokasi di Bekasi serta melakukan pengolahan bahan produksi di dalam area rumah tersebut. Store offline yang dibuka hanya satu yaitu berlokasi di alamar rumah pemilik Salaku sendiri, sedangkan store online yang dibuka yaitu melalui GoFood, GrabFood dan yang baru yaitu Shopee Food di mana pada masa sebelum pandemi pendapatan Salaku cukup meningkat disbanding pandemic menghantam seluruh perekonomian dunia. Adapun aktivitas yang dilakukan Salaku selain membuka store offline dan online yaitu Salaku giat sekali mengikuti ajang pameran dan kompetisi kuliner yang mana sudah lebih dari tiga kali Salaku mengikuti ajang kompetisi dan pameran tersebut, lalu Salaku juga melakukan catering dengan menjual menu rice box yang mana komoditas utamanya ialah sambal dari salak. Salaku memiliki pemasok salak di daerah Cibitung, Bekasi dan Salaku melakukan kerjasama dengan Pemerintahan Kota Bekasi yang mana dapat memberikan peluang koneksi lebih besar untuk ke depannya. Biaya yang dikeluarkan Salaku masih menjadi satu dengan biaya pribadi penggunaan listrik dan air di rumah pemilik usaha yang mana idealnya dalam bisnis pengeluaran pribadi dan usaha harus terpisah. 


\section{SARAN}

Adapun saran yang dapat diberikan untuk Salaku yaitu produk yang ditawarkan Salaku sudah sangat spesifik dan beragam serta masih jarang bisnis kuliner menggunakan ide buah salak bisa menghasilkan berbagai macam olahan pangan dan minuman maka Salaku hanya perlu memasarkan produknya lebih gencar agar gaungnya lebih terdengar. Jika mengikuti trend saat ini, cara memasarkan produk yang bisa dikatakan cukup efektif adalah dengan menggunakan celebrity endorsement. Apabila terkendala dengan budget, Salaku bisa menggunakan celebrity endorsement lokal Bekasi yang memiliki followers cukup tinggi. Melalui endorsement, maka produk Salaku akan lebih sering terdengar dan bisa menjadi media untuk mensosialisasikan produk yang unik terhadap pangsa pasar. Selain itu, melihat hasil pembahasan bagian customer relationship, Salaku tidak terlalu mempertahankan customer secara personal oleh karena itu perlu adanya admin khusus atau seseorang yang benar-benar bertujuan untuk me-maintain dan mem-follow up bagaimana kesan dan pesan customer terhadap produk yang sudah dikonsumsi secara intens. Berangkat dari personal experiences agar tetap memiliki pasar tersendiri maka Salaku perlu membuat suatu membership yang mana dengan membership akan mendapatkan potongan harga. Hal tersebut sering digunakan bagi pelaku bisnis dengan brand ternama dalam mempertahankan loyal customer-nya. Menambah kolaborasi pada institusi dan pusat entrepreneurship merupakan salah satu cara yang efektif dalam mengembangkan dan memperkenalkan produk olahan Salak. Pada kolaborasi tersebut, pemilik bisnis dapat berbagi ilmu dan pengetahuan begitu baiknya kandungan dari buah salak tersebut, jadi tidak hanya memandang dari sisi keuntungan bisnis namun dari sisi value. Konten yang di-posting dalam sosial media Instagram sudah cukup menarik, namun bisa ditambahkan storytelling mengenai filosofi buah salak, sejarah, perkembangan, budidaya, manfaat, maupun cara mengolah secara singkat serta perjalanan bisnis Salaku itu sendiri. Storytelling digunakan pada pelaku bisnis lain agar konten tidak terlalu kaku yang mana hanya sekedar berbagi gambar dan menjual produk namun ada sisi value yang bisa diberikan terhadap pasar agar terlihat lebih hidup dan menarik. Apabila Salaku dikemudian hari lebih berkembang, alangkah baiknya Salaku bisa memiliki offline store yang terpisah dari rumah pribadi agar beban produksi dan operasional tidak tercampur dengan beban penggunaan pribadi.

\section{DAFTAR PUSTAKA}

David, F. R. (2009). Manajemen Strategis 1: Konsep (12th ed). Salemba Empat

David, F. R. (2013). Strategic Management Concepts and cases : a competitive advantage approach (14th ed). Pearson Education Limited.

Diskominfostandi Kota Bekasi. (2021, Maret 26). Data Usaha Mikro Kecil Menengah Yang Bersertifikat Halal Tahun 2020. DANTA Pusat Sumber Data Kota Bekasi. https://danta.bekasikota.go.id/detail/data-usaha-mikro-kecil-menengah-yangbersertifikat-halal-tahun-2020

Osterwalder, A. \& Pigneur, Y. (2010). Business Model Generation : A Handbook for Visionaries, Game Changers dan Challangers. John Wiley \& Sons, Inc. 
Osterwalder, A ., Pigneur, Y., Bernarda, G., \& Smith, A. (2014). Value Proposition Design. John Wiley \& Sons, Inc.

Osterwalder, A dan Pigneur, Y. (2017). Business Model Generation : Pedoman bagi para Visioner, Penggerak Perubahan, dan Pendobrak (N. R. Sihandrini, Trans.). Elex Media Komputindo. (Karya original terbit 2010)

Rangkuti, F. (2014). Analisis SWOT Teknik Membedah Kasus Bisnis. Gramedia Pustaka Utama.

SALAKU. [@salakuolahansalak]. (2021, Maret 16). [Photograph]. Instagram. https://www.instagram.com/p/CMeNCMbr2Hk/

SALAKU. [@salakuolahansalak]. (2021, April 8). \#bolu \#buttercake \#cake \#kue \#kuebolu \#bolujadul \#boluklasik [Photograph]. Instagram. https://www.instagram.com/p/CNaF-4QrZfT/

SALAKU. [@salakuolahansalak]. (2021, April 11). [Photograph]. Instagram. https://www.instagram.com/p/CNhhmsOL6Pq/

Sugiyono. (2016). Metode Penelitian Kuantitatif, Kualitatif dan R\&D. Alfabeta

Yin, R. K. (2014). Studi Kasus Desain \& Metode. Rajawali Pers. 